\title{
Structure and Function of an RNA-Reading Thermostable DNA Polymerase**
}

\author{
Nina Blatter, Konrad Bergen, Oliver Nolte, Wolfram Welte, Kay Diederichs, Jutta Mayer, \\ Markus Wieland, and Andreas Marx*
}

The high substrate specificity of DNA-dependent DNA polymerases is essential for the stability of the genome as well as many biotechnological applications. ${ }^{[1]}$ The discrimination between ribo- and deoxyribonucleotides and between RNA and DNA, particularly in cells, is fundamental since the concentration of ribo moieties by far exceeds that of deoxyribo analogues. Although the selection mechanisms for the incorporation of nucleotides have been investigated intensively for DNA and RNA polymerases, ${ }^{[2]}$ much less is known on how DNA-dependent DNA polymerases discriminate between the different nucleic acid templates (DNA versus RNA). Some viral DNA polymerases (e.g. reverse transcriptases) can utilize both DNA and RNA as a template for nucleic acid synthesis. Crystal-structure analysis of these enzymes, complexed either to an RNA or DNA template, have contributed significantly to our understanding of this process. ${ }^{[3]}$ However, similar structural data of DNA-dependent DNA polymerases that have a poor propensity to process RNA templates are lacking, presumably because the crystallization is hampered by the formation of unstable complexes that leads to structural heterogeneity.

Structure analysis of KlenTaq DNA polymerase, a shortened form of Thermus aquaticus DNA polymerase, has added significant contributions to the understanding of how DNA polymerases recognize the cognate substrate, ${ }^{[4]}$ process abasic sites, ${ }^{[5]}$ and non-natural nucleotides. ${ }^{[4 \mathrm{~d}-\mathrm{g}]}$ Since our attempts to obtain suitable crystals of KlenTaq complexed to RNA failed, we set out to engineer the enzyme in such a way that it is capable of processing an RNA template more efficiently, which might result in improved crystallization properties. Indeed, we were able to obtain a significantly improved KlenTaq variant from which we obtained structural insights

[] M. Sc. N. Blatter, Dipl.-Biol. K. Bergen, Prof. Dr. W. Welte, Prof. Dr. K. Diederichs, Dr. J. Mayer, Dr. M. Wieland, Prof. Dr. A. Marx

Departments of Chemistry and Biology, Konstanz Research School Chemical Biology, University of Konstanz

Universitätsstrasse 10, 78457 Konstanz (Germany)

E-mail: andreas.marx@uni-konstanz.de

Priv.-Doz. Dr. O. Nolte

Labor Dr. Brunner Konstanz

Mainaustrasse 48 a/b, 78464 Konstanz (Germany)

[**:* We acknowledge support by the Konstanz Research School Chemical Biology, the Bundesministerium für Wirtschaft und Technologie, and the DFG. We also thank the staff of the Swiss Light Source (SLS) and S. Geigges and I. Grießer for their support during the crystallization trials. into a DNA-dependent DNA polymerase while processing RNA as a template for the first time. Furthermore, the generated KlenTaq variant turned out to be a thermostable DNA polymerase with significant reverse transcriptase activity, thus resulting in it being a valuable tool for crucial applications in clinical diagnostics and molecular biology, such as transcriptome analysis as well as the detection of pathogens and disease-specific markers.

For the generation of an improved enzyme variant the mutation sites of two KlenTaq (KTq) variants M1 (L322M, L459M, S515R, I638F, S739G, E773G) $)^{[6]}$ and M747K ${ }^{[7]}$ were recombined by DNA shuffling. Both variants, M1 and M747K, were reported to possess either some reverse transcriptase activity or an expanded substrate spectrum. DNA shuffling was employed since the M1 variant, previously evolved in error-prone PCR, comprises six mutations distributed over the enzyme scaffold, but the individual contributions of the mutations are unknown. We generated a library of 1570 clones to obtain high coverage of all mutation combinations (as described in the Supporting Information). Proteins were expressed in 96-well plates and, after lysis and heat denaturation of the host proteins, used in a real-time PCR activity screen with DNA as the template. As approximately $80 \%$ of the expressed enzymes were found to be PCR active, we subsequently screened for reverse transcriptase activity by using MS2 RNA as the template, as described earlier. ${ }^{[6]}$ In this screening, the two variants RTKTq 1 and RT-KTq 2 were identified and selected for further characterization as they showed significantly higher reverse transcriptase activity compared to the parental enzymes as well as a minimal number of mutations. RT-KTq1 possesses three mutations (S515R, I638F, and M747K), whereas RTKTq 2 displays the three mutations of RT-KTq1 and an additional one (L459M, Figure 1 a). For comparison, we also combined all seven mutations in one protein scaffold (KTqM1/M747K) by site-directed mutagenesis. KTq wildtype, parental enzymes M1 and M747K, KTq M1/M747K, and RT-KTq1 and 2 were expressed, purified, adjusted to equal protein concentrations (see Figure S1 in the Supporting Information), and further characterized.

First, reverse transcriptase activity of the wild-type and all variants were examined in primer extension experiments with a $5^{\prime}-\left[{ }^{32} \mathrm{P}\right]$-radiolabeled DNA primer annealed to an RNA template. Reactions were incubated at $72^{\circ} \mathrm{C}$ for $1 \mathrm{~min}$ and subsequently analyzed by denaturing PAGE (Figure $1 \mathrm{~b}$ ). When RNA was used as the template, we observed no primer elongation for the wild-type enzyme. KTq M747K incorporates up to three nucleotides, whereas KTq M1 was able to synthesize longer extension products with up to seven 
a)

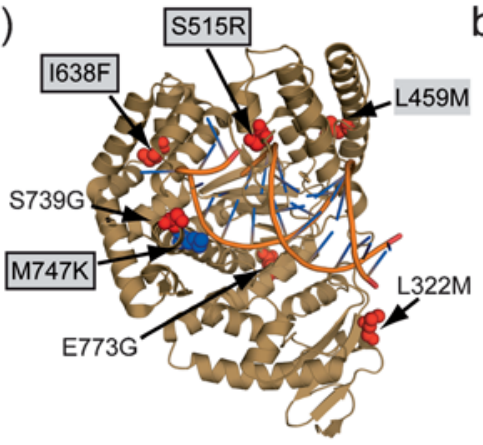

b) $5^{\prime}-\ldots$ GAT

3'-...CUA UCC AAC UAAA

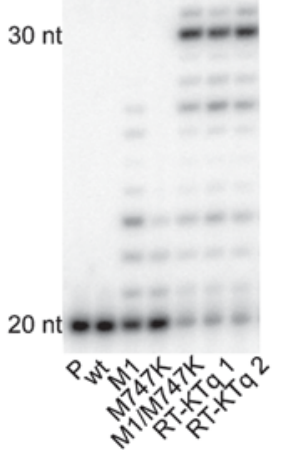

Figure 1. Characterization of KTq wild-type and mutants. a) Structure of KTq DNA polymerase (PDB 3RTV), with the mutation sites of KTq $\mathrm{M} 1$ and $\mathrm{M747K}$ highlighted in red and blue, respectively. Mutations of $\mathrm{RT}-\mathrm{KTq} 2$ are highlighted in gray, whereas mutations of RT-KTq 1 are highlighted with a black border. b) Primer extension reactions with a $5^{\prime}-\left[{ }^{32} \mathrm{P}\right]$-labeled $20 \mathrm{nt}$ primer annealed to an RNA template. The reaction mixtures were incubated for $1 \mathrm{~min}$ at $72^{\circ} \mathrm{C}$. Partial primer and template sequences are shown. $\mathrm{P}=$ primer; $w t=$ wild-type.

nucleotides elongation. KTq M1/M747K and RT-KTq1 and 2, however, showed almost quantitative formation of full-length product after $1 \mathrm{~min}$, thus exceeding the parental enzymes by far (Figure 1b). Template-independent addition of one nucleotide, as described for DNA polymerases, ${ }^{[5 a, b, 8]}$ was observed in the case of the formation of full length product.

Quantification of the respective activities ${ }^{[9]}$ on a DNA and RNA template confirmed the superiority of the identified variants $\mathrm{M} 1 / \mathrm{M} 747 \mathrm{~K}$ as well as $\mathrm{RT}-\mathrm{KTq} 1$ and 2 compared to the parental enzymes (Table 1 ). We found that the recombi-

Table 1: Specific activities of KTq variants on DNA or RNA template.

\begin{tabular}{lll}
\hline Variant & $\begin{array}{l}\text { Specific activity }{ }^{[a]}\left[\mathrm{min}^{-1}\right] \\
\text { DNA template }\end{array}$ & $\begin{array}{l}\text { Specific activity }\left[\mathrm{min}^{-1}\right] \\
\text { RNA template }\end{array}$ \\
\hline KTq wt & $145 \pm 14$ & n.a. ${ }^{[\text {b] }}$ \\
KTq M1 & $252 \pm 21$ & $1.67 \pm 0.05$ \\
KTq M747K & $279 \pm 18$ & $0.31 \pm 0.01$ \\
KTq M1/ & $342 \pm 11$ & $32.2 \pm 1.8$ \\
M747K & & \\
RT-KTq 1 & $181 \pm 12$ & $15.7 \pm 0.6$ \\
RT-KTq2 & $349 \pm 13$ & $34.9 \pm 1.3$
\end{tabular}

[a] Quantified conversion of dNTPs per minute was plotted against different polymerase amounts; the resulting slope yielded the specific activity of the respective enzyme. [b] n.a.: not accessible, since no significant activity on an RNA template was observed.

nation of two KTq mutants resulted in a new generation of KTq variants which feature an up to 20 -fold gain in reverse transcriptase activity compared to the parental variant $\mathrm{KTq}$ M1 and an up to 100-fold increase compared to KTq M747K (Table 1). If the effect of combining the mutations was additive, a twofold increase in reverse transcriptase activity would be expected. However, our results suggest an interaction between the individual mutations in a non-additive manner that results in a synergistic effect of the mutations. ${ }^{[10]}$

As a result of the higher overall activity of RT-KTq2 compared to RT-KTq1 (Table 1) and a higher stability compared to KTq M1/M747K (see Figure S2 in the Supporting Information), we focused on RT-KTq 2 for further indepth analysis. We next aimed to obtain crystals of RT-KTq2 for structural insights. Therefore, we crystallized RT-KTq2 with an 11 mer DNA primer and a 16 mer RNA template and, for comparison, with the respective primer/template DNA duplex. Details on sample preparation, crystallization, and data statistics are listed in the Supporting Information. We successfully solved structures of RT-KTq2 bound to a DNA primer/template complex and an incoming $2^{\prime}, 3^{\prime}$-dideoxycytidine-5'-triphosphate (ddCTP) at a resolution of $1.55 \AA$ (termed RT-KTq $2_{\mathrm{DNA}}$, PDB ID 4BWJ).

The overall structure of RT-KTq2 $2_{\mathrm{DNA}}$ is almost identical to closed ternary structures already described for KTq wildtype with a DNA duplex ${ }^{[4]}(\text { e.g. PDB ID 3RTV })^{[4 d]}$ and shows a low root-mean square deviation (rmsd) of $0.33 \AA$ for $\mathrm{C} \alpha$ (see Figure S3a,b in the Supporting Information). We were also able to obtain crystals of the enzyme variant in complex with a DNA/RNA hybrid at a resolution of $1.75 \AA$ (termed RT-KTq $2_{\text {RNA }}$, PDB ID 4BWM). This structure shows a halfopen state, presumably caused by crystal contacts. Interestingly, a comparison of RT-KTq $2_{\mathrm{RNA}}$ with RT-KTq $2_{\mathrm{DNA}}$ revealed major changes in the thumb domain as a result of the altered geometry of the hybrid duplex (Figure $2 \mathrm{a}$ ). The sugar moieties in the RNA template thereby adopt a puckering typical of an A-form conformation, whereas the DNA primer reveals different puckers that deviate from the typical B form (see Table S1 in the Supporting Information). ${ }^{[11]}$ The terminal three base pairs of a DNA/DNA duplex, which are adjacent to the $\mathrm{O}$ helix of the DNA polymerase, already adopt an A form. ${ }^{[4 a]}$ Therefore, structural changes in the protein scaffold were only required in regions neighboring the nucleic acids downstream of these three terminal base pairs to adapt to the changed geometry of a hybrid DNA/RNA duplex (Figure 2b). The overlay of the DNA/DNA duplex and the hybrid duplex in RT-KTq $2_{\mathrm{DNA}}$ demonstrates that part of the thumb domain would have clashed with the hybrid DNA/ RNA duplex, which required further structural adaption of the protein scaffold. Consequently, we observe a reduced number of contacts compared to RT-KTq $2_{\mathrm{DNA}}$ between the enzyme and the hybrid duplex, mainly in the $3^{\prime}$ region of the template, and several changes in the interaction pattern (see Figure S4 in the Supporting Information). Remarkably, the major part of the reordered protein scaffold originates in the thumb domain, downstream of L459M in $\alpha \mathrm{H}$ (Figure $2 \mathrm{c}$; see also Figure S3c in the Supporting Information). This shift is probably caused by the mutation of L459 to the sterically less demanding and more flexible side chain of methionine, which facilitates the bending of $\alpha \mathrm{H}$ and the subsequent movement of $\alpha \mathrm{H} 1$ and $\alpha \mathrm{H} 2$ to come in to proximity with the hybrid duplex, thereby maintaining the nucleic acid binding characteristics of this motif (Figure $2 \mathrm{c}$ ). ${ }^{[4 a]}$ This motif is stabilized by the S515R mutation located in $\alpha \mathrm{H} 2$. The arginine residue displays two conformations in the RT-KTq $2_{\mathrm{RNA}}$ structure, thus allowing interactions with the hydroxy group of S513 and the peptide backbone of K505 (Figure 2d). The role of I638F is less apparent, although it probably accounts for a tighter 
a)

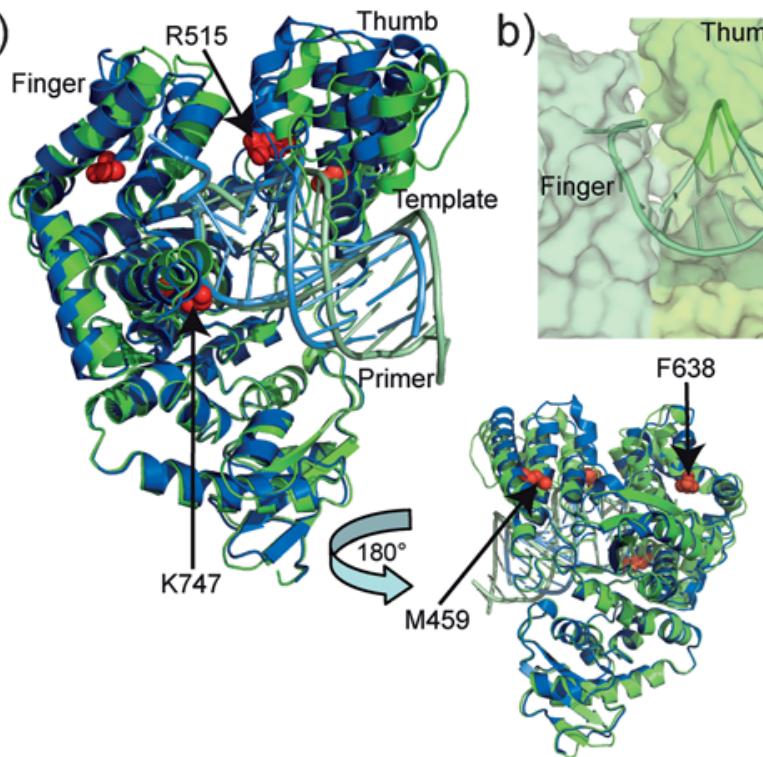

humb

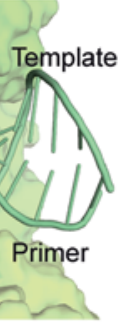

c)

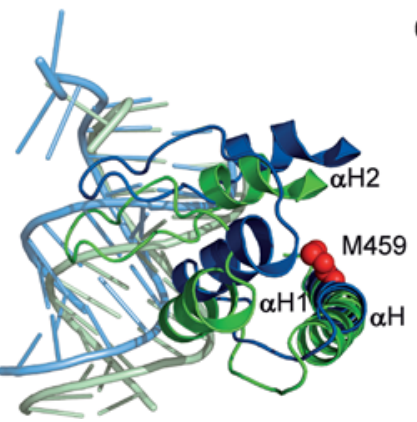

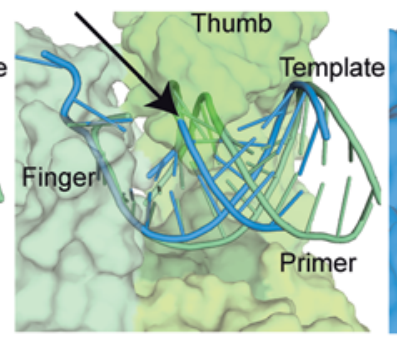

d)
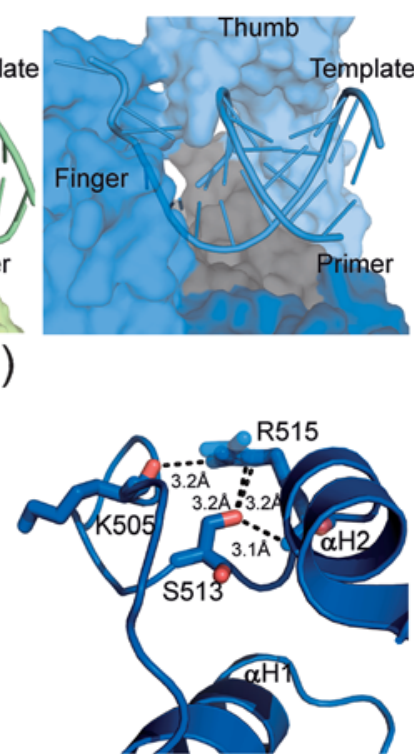

Figure 2. Crystal structures of RT-KTq $2_{\mathrm{DNA}}$ and RT-KTq $2_{\mathrm{RNA}}$. a) Structure of RT-KTq $2_{\mathrm{DNA}}$ (green) superimposed with RT-KTq $2_{\text {RNA }}$ (blue). The DNA duplex and DNA/RNA hybrid are colored in pale green and pale blue, respectively. Mutation sites are highlighted as red spheres. b) Close-up view showing the DNA duplex in RT-KTq $2_{\text {DNA }}$ (left), overlay of the DNA and hybrid duplex in RT-KTq $2_{\text {DNA }}$ (middle), and the DNA/RNA hybrid duplex in $\mathrm{RT}-\mathrm{KTq} 2_{\mathrm{RNA}}$ (right). The overlay of the hybrid and the DNA duplex highlights the need for a rearrangement of the thumb domain because of the altered geometry of the DNA/RNA hybrid that would clash with the enzyme (highlighted with the arrow). c) Close-up view highlighting the position of the M459 mutation on $\mathrm{H}$ helices. M459 is depicted as a red sphere. d) Close-up view highlighting the interactions involving mutation S515R. R515 is depicted as blue sticks. An alternative conformation is transparent.

folding of the finger domain through hydrophobic and $\pi-\pi$ stacking interactions with neighboring amino acids. In contrast to the RT-KTq2 $2_{\text {DNA }}$ structure, R515 and F638 are resolved in simulated annealing omit maps, indicating a stabilization of the corresponding region and further corroborating our observations (see Figure S3d,e in the Supporting Information). Finally, the mutation M747K enhances the positively charged surface potential in proximity to the negatively charged backbone of the DNA. ${ }^{[5 b]}$ This might promote binding of the nucleic acid backbone and thus, foster the ability to accept aberrant substrates. Interestingly, this is analogous to a finding where a positive charge introduced into the thumb subdomain of a thermostable DNA polymerase allows more efficient processing of a noncognate RNA primer/DNA template duplex by incorporation of ribonucleotide substrates. $^{[12]}$

Next, the potential of RT-KTq2 to be applied in molecular biology or clinical diagnostics was investigated by performing reverse-transcription polymerase chain reaction (RT-PCR) experiments. RNA is the template for transcriptome analysis, for pathogen detection, as well as for diseasespecific marker recognition in RT-PCR. ${ }^{[13]}$ This method is based on the detection and quantification of RNA by the enzyme-mediated reverse transcription of RNA to its complementary DNA and a subsequent amplification by PCR, thereby allowing the abundance of specific RNA molecules to be monitored in real time. Since the DNA polymerases employed in standard PCR are lack sufficient reverse transcriptase activity, two enzymes are required for RT-PCR: a reverse transcriptase and a PCR-competent DNA polymerase. Although these two enzyme mixtures are state of the art, several drawbacks arise from the heat-instability of commonly used retroviral mesophilic reverse transcriptases ${ }^{[14]}$ such as unspecific priming, low yield on complex targets, for example, from secondary structure formation of the mRNA template, and premature reaction termination. ${ }^{[13 \mathrm{a}]}$ In addition, the reverse transcription step usually adds up to $30 \mathrm{~min}$ to the PCR protocol, a time addition which during outbreak situations - when hundreds of swabs need to be analyzedprovides a critical bottleneck. Thus, thermostable DNA polymerases capable of reverse transcription and PCR would supersede the use of two enzymes and reduce the time and work. First, the purified enzymes were used in realtime RT-PCR experiments using MS2 bacteriophage RNA as the template. ${ }^{[6]}$ Under the conditions studied, RT-KTq 2 leads to product formation approximately 10 cycles earlier than the parental enzyme KTq M1, whereas the wild-type enzyme has no detectable activity (Figure $3 \mathrm{a}$ ). Formation of the expected product was confirmed by analysis on an agarose gel. Additionally, we demonstrated that RT-KTq 2 is able to generate significantly longer products than the parental enzyme KTq M1 (see Figure S5 in the Supporting Information). To investigate the application of RT-KTq2 for the detection of various mRNA transcripts from extracted human total RNA isolated from Jurkat cells, products ranging from 71 to 111 base pairs (bp) were amplified by RT-PCR (Figure $3 \mathrm{~b}$ ). Amplification through DNA contamination could be excluded by choosing intron-spanning targets. Ultrafast two-step cycling was employed in this experiment, with only $30 \mathrm{~s}$ initial denaturation at $98^{\circ} \mathrm{C}$ and 30 cycles of two-step cycling with denaturation for $2 \mathrm{~s}$ and $15 \mathrm{~s}$ for combined annealing/extension at the temperature indicated. 
a)
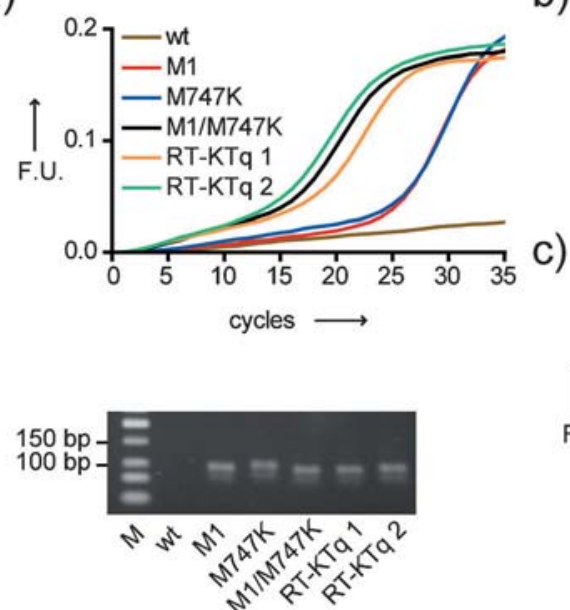

b)

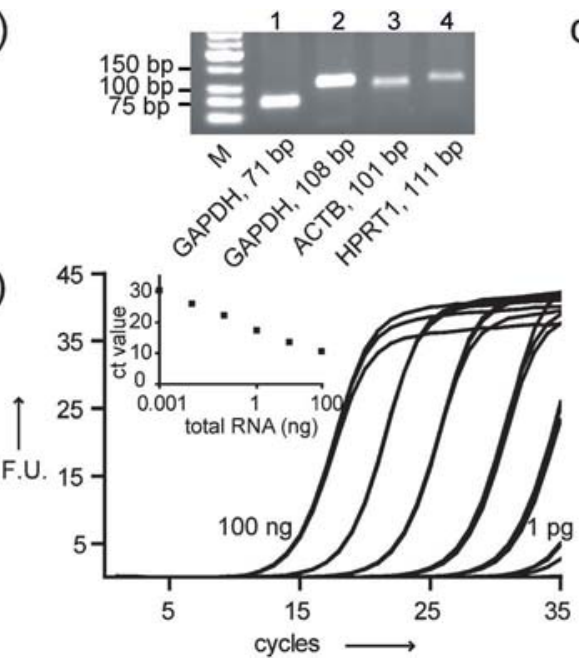

d)

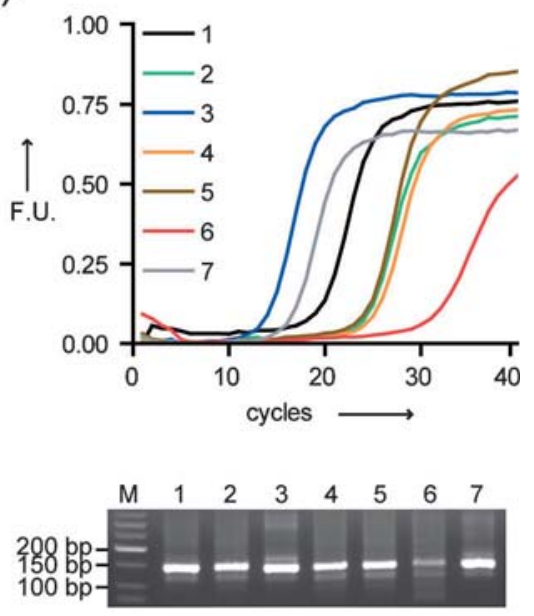

Figure 3. RT-PCR using RT-KTq2. a) Real-time RT-PCR performed with wild-type (wt), M1, M747K, M1/M747K, RT-KTq 1 and 2 (as indicated) used to amplify a $100 \mathrm{bp}$ target sequence from MS2 bacteriophage RNA. The fluorescence readout was based on the binding of SYBRGreen I to double-stranded DNA. Product formation was analyzed on a $2.5 \%$ agarose gel. M: Marker; F.U. = fluorescence units. b) Detection of mRNA transcripts from human total RNA (Jurkat cells) in about 20 min using ultrafast PCR. Target amplicons: GAPDH (71 bp; 108 bp, annealing/ extension at $61^{\circ} \mathrm{C}$ ), actin (ACTB; $101 \mathrm{bp}$, annealing/extension at $72^{\circ} \mathrm{C}$ ), and hypoxanthine phosphoribosyltransferase 1 (HPRT1; $111 \mathrm{bp}$, annealing/extension at $63^{\circ} \mathrm{C}$ ) in lanes 1, 2, 3, and 4, respectively. M: Marker. c) Real-time RT-PCR employing a tenfold dilution series of total RNA (Jurkat cells) in which a 90 bp fragment from human $\beta$-actin was amplified. Dilution series ranged from $100 \mathrm{ng}$ to 1 pg total RNA. Reactions were performed in triplicates. Inset: Ct (cycle threshold) values plotted against the amount of total RNA. d) Detection of influenza virus A from RNA extracts of seven different specimens. Product formation was analyzed on a $2.5 \%$ agarose gel. M: Marker.

Also, an additional reverse transcription step was omitted, thus saving further time. Thus, RNA detection was achieved in approximately $20 \mathrm{~min}$. Expected product formation was observed for all targets (Figure $3 \mathrm{~b}$ ). Additionally, we investigated the sensitivity of RT-KTq2 for RNA detection by performing real-time RT-PCR experiments. A 90 nucleotide (nt) RNA stretch of human $\beta$-actin mRNA was targeted and amplified from total RNA isolated from Jurkat cells (Figure $3 \mathrm{c}$ ). Again, two-step cycling was used for the PCR, and product formation was visualized by the binding of SYBRGreen I. We demonstrated that RNA detection was linear over a broad range of concentrations, from $100 \mathrm{ng}$ to as low as $1 \mathrm{pg}$ of RNA, thus competing with commercially available enzymes (see Figure S6 in the Supporting Information).

Next, we set out to detect the influenza virus $A$ in TaqMan-based real-time RT-PCR by using RT-KTq2. Influenza viruses have been the cause of several pandemics; $;^{[15]}$ therefore, rapid detection methods are required to identify new outbreaks early for subsequent medical intervention. As 5 '-nuclease activity is needed for the hydrolysis of duallabeled TaqMan probes, we used an enzyme blend of Taq DNA polymerase wild-type and RT-KTq 2 in our assay. RNA extracts were from respiratory swab samples of patients known to be influenza A positive. A 141 nt RNA stretch coding for the influenza A matrix protein was targeted in realtime RT-PCR by using two-step cycling. Furthermore, a TaqMan probe conjugated with minor groove binders ${ }^{[16]}$ was used to increase the reaction specificity in addition to optimized primers recommended for the detection of influenza A. An increase in the fluorescence signal was observed for seven different specimens; correct product formation was visualized on an agarose gel (Figure $3 \mathrm{~d}$ ).
In summary, we have reported the first structure of a DNA-dependent DNA polymerase, whose wild-type ancestor has no significant reverse transcriptase activity, incorporating a nucleotide against an RNA target. The results highlight the altered structure of the DNA/RNA duplex compared to the DNA/DNA duplex. Additionally, crucial amino acid sites were identified that prevent the wild-type enzyme from efficiently using RNA as the template. Whereas the mutation $\mathrm{M} 747 \mathrm{~K}$ might increase binding affinity to any negatively charged nucleic acid, S515R stabilizes the nucleic acid binding motif in the thumb domain. L459M results in an increased flexibility of the thumb domain, which contributes to preventing a clash with a DNA/RNA hybrid duplex. Furthermore, we have reported some very promising properties of the variant that allow applications such as fast detection and quantification of RNA by RT-PCR in approximately $20 \mathrm{~min}$. The enzyme facilitates multiple applications such as rapid transcription analysis as well as the detection of RNA and DNA pathogens. Since RT-KTq2 exhibits reverse transcriptase and PCR activity in a single enzyme, it has great potential for minimizing labor and time-consuming optimizations without compromising reliable analysis.

Received: July 30, 2013

Revised: August 16, 2013

Published online: September 17, 2013

Keywords: DNA polymerases · enzyme engineering · polymerase chain reaction - reverse transcription . structural biology 
[1] T. A. Kunkel, K. Bebenek, Annu. Rev. Biochem. 2000, 69, $497-$ 529.

[2] a) M. Ricchetti, H. Buc, EMBO J. 1993, 12, 387-396; b) C. M. Joyce, Proc. Natl. Acad. Sci. USA 1997, 94, 1619-1622 and references therein; c) P. H. Patel, L. A. Loeb, J. Biol. Chem. 2000, 275, 40266-40272; d) M. Ogawa, A. Tosaka, Y. Ito, S. Yoshida, M. Suzuki, Mutat. Res. 2001, 485, 197-207; e) G. Xia, L. Chen, T. Sera, M. Fa, P. G. Schultz, F. E. Romesberg, Proc. Natl. Acad. Sci. USA 2002, 99, 6597-6602; f) J. L. Ong, D. Loakes, S. Jaroslawski, K. Too, P. Holliger, J. Mol. Biol. 2006, 361, 537-550; g) S. A. N. McElhinny, D. Kumar, A. B. Clark, D. L. Watt, B. E. Watts, E. B. Lundstrom, E. Johansson, A. Chabes, T. A. Kunkel, Nat. Chem. Biol. 2010, 6, 774-781; h) J. A. Brown, Z. Suo, Biochemistry 2011, 50, 1135-1142; i) W. Wang, E. Y. Wu, H. W. Hellinga, L. S. Beese, J. Biol. Chem. 2012 287, 28215-28226.

[3] a) L. A. Kohlstaedt, J. Wang, J. M. Friedman, P. A. Rice, T. A. Steitz, Science 1992, 256, 1783-1790; b) A. Jacobo-Molina, J. Ding, R. G. Nanni, A. D. Clark, Jr., X. Lu, C. Tantillo, R. L. Williams, G. Kamer, A. L. Ferris, P. Clark, Proc. Natl. Acad. Sci. USA 1993, 90, 6320-6324; c) H. Huang, R. Chopra, G. L. Verdine, S. C. Harrison, Science 1998, 282, 1669-1675; d) J. Ding, K. Das, Y. Hsiou, S. G. Sarafianos, A. D. Clark, Jr., A. Jacobo-Molina, C. Tantillo, S. H. Hughes, E. Arnold, J. Mol. Biol. 1998, 284, 1095-1111; e) S. G. Sarafianos, K. Das, C. Tantillo, A. D. Clark, Jr., J. Ding, J. M. Whitcomb, P. L. Boyer, S. H. Hughes, E. Arnold, EMBO J. 2001, 20, 1449-1461; f) E. Nowak, W. Potrzebowski, P. V. Konarev, J. W. Rausch, M. K. Bona, D. I. Svergun, J. M. Bujnicki, S. F. Le Grice, M. Nowotny, Nucleic Acids Res. 2013, 41, 3874-3887.

[4] a) Y. Li, S. Korolev, G. Waksman, EMBO J. 1998, 17, 75147525; b) Y. Li, V. Mitaxov, G. Waksman, Proc. Natl. Acad. Sci. USA 1999, 96, 9491 -9496; c) Y. Li, G. Waksman, Protein Sci. 2001, 10, 1225-1233; d) K. Betz, D. A. Malyshev, T. Lavergne, W. Welte, K. Diederichs, T. J. Dwyer, P. Ordoukhanian, F. E.
Romesberg, A. Marx, Nat. Chem. Biol. 2012, 8, 612-614; e) S. Obeid, H. Busskamp, W. Welte, K. Diederichs, A. Marx, Chem. Commun. 2012, 48, 8320-8322; f) K. Bergen, A.-L. Steck, S. Strütt, A. Baccaro, W. Welte, K. Diederichs, A. Marx, J. Am. Chem. Soc. 2012, 134, 11840-11843; g) S. Obeid, A. Baccaro, W. Welte, K. Diederichs, A. Marx, Proc. Natl. Acad. Sci. USA 2010, 107, 21327-21331.

[5] a) S. Obeid, N. Blatter, R. Kranaster, A. Schnur, K. Diederichs, W. Welte, A. Marx, EMBO J. 2010, 29, 1738-1747; b) S. Obeid, A. Schnur, C. Gloeckner, N. Blatter, W. Welte, K. Diederichs, A. Marx, ChemBioChem 2011, 12, 1574-1580; c) S. Obeid, W. Welte, K. Diederichs, A. Marx, J. Biol. Chem. 2012, 287, 1409914108.

[6] K. B. Sauter, A. Marx, Angew. Chem. 2006, 118, 7795-7797; Angew. Chem. Int. Ed. 2006, 45, 7633-7635.

[7] C. Gloeckner, K. B. Sauter, A. Marx, Angew. Chem. 2007, 119, 3175-3178; Angew. Chem. Int. Ed. 2007, 46, 3115-3117.

[8] J. M. Clark, Nucleic Acids Res. 1988, 16, 9677-9686.

[9] N. Z. Rudinger, R. Kranaster, A. Marx, Chem. Biol. 2007, 14, $185-194$

[10] M. T. Reetz, Angew. Chem. 2013, 125, 2720-2729; Angew. Chem. Int. Ed. 2013, 52, 2658-2666.

[11] O. Fedoroff, M. Salazar, B. R. Reid, J. Mol. Biol. 1993, 233, 509523.

[12] C. Cozens, V. B. Pinheiro, A. Vaisman, R. Woodgate, P. Holliger, Proc. Natl. Acad. Sci. USA 2012, 109, 8067-8072.

[13] a) S. A. Bustin, J. Mol. Endocrinol. 2000, 25, 169-193; b) S. A. Bustin, R. Mueller, Clin. Sci. 2005, 109, 365-379.

[14] G. F. Gerard, R. J. Potter, M. D. Smith, K. Rosenthal, G. Dhariwal, J. Lee, D. K. Chatterjee, Nucleic Acids Res. 2002, 30, 3118-3129.

[15] P. Palese, Nat. Med. 2004, 10, S82-87.

[16] I. V. Kutyavin, I. A. Afonina, A. Mills, V. V. Gorn, E. A. Lukhtanov, E. S. Belousov, M. J. Singer, D. K. Walburger, S. G. Lokhov, A. A. Gall, R. Dempcy, M. W. Reed, R. B. Meyer, J. Hedgpeth, Nucleic Acids Res. 2000, 28, 655-661. 